\title{
Multinational Banks and the Performance of Their Subsidiaries Abroad
}

\author{
Oskar Kowalewski* \\ Institute of Economics, Polish Academy of Sciences, World Economy Research Institute, Warsaw School of Economics \\ *Corresponding author: okowale@sgh.waw.pl
}

Received March 02, 2014; Revised March 11, 2014; Accepted March 16, 2014

\begin{abstract}
This paper investigates whether foreign subsidiaries outperform their parent banks in terms of profitability and what determines this outcome. Using a sample of multinational banks and their subsidiaries in a large number of countries, this study shows that, on average, foreign subsidiaries are less profitable than their parent banks. However, the results show that foreign subsidiaries tend to perform better than their parent banks if they are well capitalized, have low overhead costs and loss low provision. I find also show that foreign subsidiaries tend to perform better than their parent banks if the latter are underperforming in the home market. While, the legal distance between host country and host country is an important determinant of the profitability of the subsidiary in relation to its parent bank, to a lesser extent, are the host market's characteristics. Finally, foreign banks are more likely to outperform parent banks in developing markets than in developed countries. However, different bank and host country determinants influence the profitability of the subsidiaries in these countries.
\end{abstract}

Keywords: international banking, foreign banks, subsidiary, performance

Cite This Article: Oskar Kowalewski, "Multinational Banks and the Performance of Their Subsidiaries Abroad.” Journal of Finance and Economics, vol. 2, no. 3 (2014): 90-100. doi: 10.12691/jfe-2-3-6.

\section{Introduction}

It is generally assumed that multinational banks expand abroad with the aim of increasing their overall profitability. Hence, many studies have compared the performance of foreign banks to domestic banks in host markets and have found contradictory results. In developing countries, most empirical studies have shown that foreign banks tend to outperform domestic banks in terms of profitability and efficiency (Demirgüç-Kunt and Huizinga, 2000). On the contrary, in developed countries, studies have documented that foreign subsidiaries tend to perform poorly when compared to their domestic counterparts (Classens and van Horen, 2009). None of the existing studies, however, have presented how the foreign subsidiaries perform in relation to their parent banks, which may be important in understanding why banks expand abroad even though they may underperform in the host markets in comparison to domestic banks.

Using the parent banks as a benchmark in measuring the performance of the foreign bank subsidiaries allows not only to investigates its profitability but takes into account the short coming of the existing studies. These studies used as peer group domestic banks either from developed or developing countries. Henceforth, it is not surprisingly that the results differed as the banking system and banks differ significantly in these countries. While, employing only parent banks as benchmark may control for the shortcoming and provide an answer whether foreign banks indeed underperform in developed countries and outperform in emerging markets.
In using a new approach this study tries to fill the existing gap on foreign bank performance by considering the performance and factors that determine the profitability of the subsidiaries abroad relative to their parent banks. Specifically, this study examines the differences in the performance between the foreign-owned subsidiaries and their parent banks, measured in terms of profitability, in a large group of countries over the period between1989 and 2008.In the regression framework, the effects of bank-specific, ownership-specific and macrodeterminants on profitability are analyzed, and the large number of countries in the sample enables to exploit the variation in host and home country characteristics.

The results of this study reveal that, on average, foreign bank subsidiaries are less profitable than their parent banks. Indeed, the results show that what determines the subsidiaries' profitability is the inefficiency of the parent bank in the home market. This means that foreign subsidiaries are outperforming their parent banks only if the latter is underperforming in the home market. This relationship is present regardless if the foreign bank is operating in developed or emerging country. The results, however, also show that foreign bank determinants are also important. Subsidiaries that are well capitalized and have low loss provisions and overhead costs are outperforming their parent banks in terms of profitability. In emerging markets size of the foreign bank seems to matter, while it is not important in developed countries. Moreover, in line with the literature the results show that foreign banks outperform parent banks in less developed countries and highly concentrated banking sectors. Finally, the results also reveal that the legal distance between the 
host and home countries is important, whereas geographical distance additionally explains the differences in relative performance of foreign banks in developed countries to its parent banks.

The results of this study add to the literature in several ways. Most important, it extends the literature on the performance of foreign banks by showing the results in relation to the parent bank, which has been ignored in the past. Second, it expands the limited literature on the ownership factors that affect a foreign bank's ability to operate in a host country, as expressed in Williams (2003) and Sturm and William (2010). In this study, I explicitly analyze the impacts of some specific parent bank characteristics, and the results reflect evidence from a large number of countries. As such, it provides an explanation for some of the contradicting results found in the literature in the past. Third, by studying the impact of macroeconomic factors and the distance between home and host markets, the study contributes to the rapidly increasing literature on their impact on the performance of foreign banks. Finally, the study provides new evidence on the performance of foreign banks subsidiaries in developed or developing countries.

I organize the rest of the paper as follows. The next section reviews the theoretical predictions regarding the factors that may affect foreign bank performance. Section 3 describes the variable selection used in this study. Section 4 introduces the data and presents univariate statistics. Section 5presents the estimation method and the empirical results, while Section 6 concludes and provides directions for further research.

\section{Literature Review}

In the literature on multinational banking, the determinants of banks' profitability are usually dichotomized into internal and external factors. The internal factors focus on bank-specific features, while external factors consider the location-specific factors. I discuss them all briefly in what follows.

The research on internal-specific factors emphasizes the importance of banks' assets and liabilities structures on their performance. It argues that foreign banks differ in the funding and asset mix from domestic banks, which can be an explanation for its underperformance in some of the foreign markets. DeYoung and Nolle (1996), for example, argued that, in the US, foreign banks are less profit efficient as a consequence of their reliance on purchased funds. In Europe, Molyneux et al. (1998) presented evidence that the profitability of foreign banks is related to their capital ratios, commercial and industrial loan growth, and asset portfolio composition. Individual country studies confirmed that more profitable banks have, on average, lower costs of funds, greater use of transaction deposits, more marketable securities and higher capitalization (Wall, 1985).

The ownership specifics are related to the parent bank's characteristics, which may affect the performance of their subsidiaries abroad. Ursacki and Vertinsky (1992) documented that the most important variables determining the timing of foreign bank entry into a host market are the size and the existing level of geographical diversification of the parent bank. Later, Berger et al. (2000) suggested that there is some evidence showing that banks that perform well at home also perform well abroad. Minh To and Tripe (2002) argued that a more profitable bank could result in increased profitability in foreign markets. The positive impact of the parent bank's profitability on foreign subsidiaries was confirmed by Kosmidou et al. (2007). On the contrary, Williams (2003) did not find parent bank profits to affect foreign subsidiaries in Australia. Hence, the studies on the effects of the parent bank on their subsidiaries in the host markets are not only scarce but also inconsistent.

The impact of macroeconomic variables and host country financial structures on bank performance has been highlighted by Demirgüç-Kunt and Huzinga (1999), who reported that macroeconomic and regulatory conditions have a pronounced impact on profitability and margins. In particular, they found that foreign banks have higher margins and profits as compared to domestic banks in developing countries, while the opposite holds in developed countries. Furthermore, the authors documented that lower market concentration ratios lead to lower margins and profits, while the effect of foreign ownership varies between industrialized and developing countries.

Recently, the distance between host and home market has also been considered as an additional location-specific advantage. The reason for this is that the cost of monitoring investment grows with distance. Consequently, since the cost of monitoring clients is higher in distant markets, it should constitute a barrier to entry and as a result makes banks less willing to invest in countries far away from the home market. Moreover, Berger et al. (2001) suggested that efficiency barriers, such as geographical distance, different languages and cultures, or regulations, impede cross-border activity and therefore offset some of the gains of cross-border consolidation. Those assumptions were confirmed by Correa (2008), who showed that, in industrialized countries, the post acquisition performance of cross-border banks is higher when host and home country share the same language but is lower when they share the same legal system.

Overall, the existing literature provides a rather comprehensive account of the effect of internal and location-specific determinants on bank profitability, but the effects of ownership (parent) are not very well known. Therefore, the focus of this study is to unify all of these factors into a single model in order to provide new insight on the factors that affect foreign subsidiaries' profitability relative to their parent banks.

\section{Determinants and Variable Selection}

The aim of the study is to establish the determinants of profitability of foreign subsidiaries relative to the performance of the parent bank. I do this using a dependent variable, which is the difference between the profitability of the foreign-owned subsidiary and its parent. As the profitability measure, I consider the bank's return on assets (ROA), which is calculated using the profit before taxes. Therefore it eliminates any possible influence of the different tax systems in the results of the analyses. Moreover, ROA is not distorted by high equity multipliers, and hence represents a better measure of bank 
performance than the alternative proxy, which is the return on equity (Rivard and Thomas, 1997). On the other hand, ROA may be biased due to off-balance-sheet activities, yet I believe such activities are negligible in banks' subsidiaries abroad.

Henceforth, an additional dependent variable is used in the study to measure the efficiency of the foreign subsidiaries. The difference in net interest margin between the foreign subsidiary and its parent bank (NIM) is employed as an alternative measure of profitability. The interest income has a significant impact on the profitability of the subsidiary abroad and may also be influenced by the ownership effects.

As for the potential determinants of bank performance, the literature suggests that such determinants are internal bank-specific factors, ownership-specific factors and location-specific factors. Considering those factors in turn, the chosen set of independent variables is discussed. A description of all of the variables provides Table 1 .

Table 1. Variables definition

\begin{tabular}{|c|c|c|}
\hline \multicolumn{2}{|c|}{ Variables } & Description \\
\hline \multirow{2}{*}{ Dependent } & ROA & $\begin{array}{l}\text { The difference in ROA of the foreign subsidiary and parent bank, where ROA is calculated as } \\
\text { pretax income divided by total assets }\end{array}$ \\
\hline & NIM & $\begin{array}{l}\text { The difference in NIM between the foreign subsidiary and its parent bank, where NIM is } \\
\text { calculated as net interest income divided by total assets }\end{array}$ \\
\hline \multirow{7}{*}{ Bank specific } & Loss $_{\mathrm{s}}$ & Loan loss provisions to net interest revenues \\
\hline & Loans $_{\mathrm{s}, \mathrm{p}}$ & Total loans divided by total assets \\
\hline & Costs $_{\mathrm{s}}$ & Non interest expenses divided by total assets \\
\hline & Capital $_{\mathrm{s}}$ & Equity divided by total assets \\
\hline & Assets $_{\mathrm{s}, \mathrm{p}}$ & Natural log. of the total assets of the foreign subsidiary \\
\hline & dROA & $\begin{array}{l}\text { The difference in ROA of the parent bank and the average ROA for all banks in the home } \\
\text { country }\end{array}$ \\
\hline & dNIM & $\begin{array}{l}\text { The difference in NIM between the parent bank and the average NIM for all banks in the home } \\
\text { country }\end{array}$ \\
\hline \multirow{3}{*}{ Macro-economic } & GDP & Logarithm of GDP per capita \\
\hline & Growth & Annual growth rate of GDP \\
\hline & CR5 & $\begin{array}{l}\text { The concentration ratio calculated by dividing the assets of the five largest banks with the total } \\
\text { assets of all banks }\end{array}$ \\
\hline \multirow[b]{2}{*}{ Distance } & Region & Dummy which is 1 if home and host country share the same geographical region, 0 otherwise \\
\hline & Law & $\begin{array}{l}\text { Dummy variable set equal to } 1 \text { if the same legal system prevails in the home and host country, } 0 \\
\text { otherwise }\end{array}$ \\
\hline
\end{tabular}

Variables $\mathrm{x}_{\mathrm{S}}$ and $\mathrm{x}_{\mathrm{p}}$ are for foreign bank subsidiaries or its parent banks, respectively. The data for calculating the bank specific variables and for country-specific variables were obtained from BankScope, Beck and Demirgüç-Kunt (2009), Laeven and Valencia (2010) and World Bank Development Indicators.

\subsection{Internal Bank Factors}

First, I control for bank-specific characteristics to see whether they determine the performance of the foreign bank subsidiary using Loss-loans provisions to interest revenues, and Loans, noninterest expenses (Cost), Equity to total assets as well as the log of the total Assets.

Lower loan loss provision and higher loans should positively influence foreign subsidiaries' performance. DeYoung and Nolle's (1996) and Peek et al. (1999)documented that foreign banks were conducting an aggressive loan policy, which, combined with their funding structures, may be a reason why they were underperforming in comparison to their domestic peers. On the other hand, studies using developing countries as a sample have shown that foreign banks are profitable despite their average stronger loan growth and lesser reliance on deposits than domestic banks (Crystal et al., 2001).

The results obtained in the literature for the relationship between size and profits are diverse, yet I expect a positive relationship between equity and assets and foreign bank performance. Berger (1995) has shown that well-capitalized banks provide a signal to the market and document positive causation in both direction between capital and profitability. Similarly, Smirlock (1985) documented a positive and significant relationship between size and bank profitability. By contrast, Berger et al. (1987) found that as product mixes and scales increase, banks experience some diseconomies, implying a negative relationship between size and returns.

\subsection{Ownership-specific Factors}

Second, I control for parent-specific factors using Loans to total assets and the log of the total Assets. In contrast to the internal factors, the existing studies present limited evidence on the parents' effects on subsidiaries' performance.

I expect loans to be negatively related to subsidiaries' performance as they may signal the higher profitability of the home market banking operation than of the host market. Recently, de Haas and van Lelyveld (2010) provided evidence for the existence of internal capital markets through which multinational banks manage the credit growth of their foreign subsidiaries. They have shown that foreign subsidiaries expand lending faster when economic growth in the parent bank's home country decreases, yet the results for the substitution effects were weak. As for evidence, Ursacki and Vertinsky (1992) found parent size to be important in determining the size of subsidiaries in the host nation, whereas Williams and Sturm (2010) found it to be insignificant.

In addition to the bank-level variables, two different variables are used to control for parent efficiency in the home market, which may provide a source of competitive advantage in the host markets (Minh To and Tipe, 2002). The difference in the return on assets $(d R O A)$ or net interest margin $(d N I M)$ of the parent bank and the industry 
in the home market is used to control for parent's profitability efficiency when either ROA or NIM is employed as a dependent variable. It is expected that those two variables are positively related to foreign subsidiaries' performance, yet the existing results are again mixed. Williams and Sturm (2010) did not find that parent profitability has any effect on foreign bank performance in Australia; by contrast, Kosmidou et al. (2007) found it to be significant for foreign subsidiaries of Greek multinational banks.

\subsection{Macroeconomic and Industry-specific Factors}

Third, the impact of macroeconomic and industryspecific factors on bank performance has recently been highlighted in the literature. The variable log of GDP per capita captures the potential for scale economies in the host country (Buch and DeLong, 2004).Economic Growth is used as a proxy for the attractiveness of the local market. While, the share of the five largest banks in total assets of the banking sector is used to measure concentration (CR5), as Berger (1995) provided evidence that superior management and increased market share raise profits. Hence, all three variables are expected to be positively related to subsidiaries' profits.

\subsection{Distance Factors}

Classens and van Horen (2009) documented that the relative performance of foreign banks is better when the geographical, cultural and institutional distance is small. In contrast, they showed that foreign banks perform better when the economic distance is large, whereas the parent's home country has a higher level of development than the host country. To control for the effects of distance, the following two explanatory variables are included.

Geographical and cultural aspects are represented using Region, which equals one if host and home countries are located in the same continent. The variable represent the information costs (Buch and DeLong, 2004), but the institutional aspects may also be important (Mian, 2006). Therefore, a dummy, Law, is used, which equals one if the countries have the same legal origins, to control for the differences in the institutional environment in the host and home countries. Moreover, the law dummy is strongly correlated with a language dummy, which equals one if the official language in both countries is the same. Consequently, the dummy law may be used as proxy for cultural differences between the host and home countries. However, the language dummy was not significant in the regression and therefore the results are not reported for brevity.

\section{Data and Univariate Statistics}

To select the multinational banks that constitute the sample of the study, a list of the world's 150 largest banks (asset rank) was prepared using the2008 ranking of banks published by the magazine The Banker. From this list, multinational banks were selected for further examination if they owned at least $50 \%$ in one bank abroad, and the financial statement for the bank and its foreign subsidiary was available in the BankScope database. Moreover, for the parent bank, unconsolidated financial data were retrieved, whereas for the foreign subsidiaries, consolidated financial statements was used.

Using this approach, a final sample was constructed that included 62 multinational banks, mainly from the US, Western Europe and East Asia, and 288 subsidiaries in developed and developing countries. Additional countryspecific and market-specific data were drawn mainly from the WDI database as well as from the World Bank's Financial Structure Database (Beck and Demirgüç-Kunt, 2010). A sample of 1,533 observations on each variable made up an unbalanced panel covering the period between 1989 and 2008, whereas in some of the regressions, the number was reduced because all of the variables were not always available for the multinational banks in the sample.

\subsection{Univariate Results}

Table 2 displays panel means and standard deviations for the multinational banks and foreign subsidiaries. The last column in the table presents the results of t-statistic tests for the difference in the means between the parent bank and its subsidiary, whereas the results confirm that both groups differ significantly in terms of profitability, costs, assets and liabilities structures.

Table 2. Summary statistics and univariate comparison

\begin{tabular}{|c|c|c|c|c|c|c|c|}
\hline \multirow{2}{*}{ Variables } & \multirow[b]{2}{*}{$\mathrm{N}$} & \multicolumn{2}{|c|}{ Parent } & \multicolumn{2}{|c|}{ Subsidiary } & \multicolumn{2}{|c|}{ Differences } \\
\hline & & mean & stdev & mean & stdev & mean & stdev \\
\hline Pretax income & 3585 & 0.045 & 0.125 & 0.016 & 0.055 & $0.029^{* * *}$ & 0.135 \\
\hline Net interest income & 3118 & 0.024 & 0.049 & 0.029 & 0.038 & $-0.004^{* * *}$ & 0.061 \\
\hline Non-interest income & 3192 & 0.017 & 0.074 & 0.022 & 0.276 & -0.005 & 0.281 \\
\hline Overhead costs & 3133 & 0.021 & 0.030 & 0.050 & 0.220 & $-0.029^{* * *}$ & 0.222 \\
\hline Tax & 2819 & 0.002 & 0.008 & 0.005 & 0.010 & $-0.002^{* * *}$ & 0.013 \\
\hline Equity & 4154 & 0.230 & 0.314 & 0.126 & 0.128 & $0.104^{* * *}$ & 0.344 \\
\hline Loans & 3071 & 0.413 & 0.190 & 0.428 & 0.239 & $-0.016^{* * *}$ & 0.305 \\
\hline Deposits & 3067 & 0.586 & 0.217 & 0.712 & 0.216 & $-0.126^{* * *}$ & 0.321 \\
\hline Securities & 2911 & 0.180 & 0.098 & 0.192 & 0.189 & $-0.013^{* * *}$ & 0.211 \\
\hline
\end{tabular}

Note: All variables presented as a percentage of total assets with the exception of the variable assets, which was calculated as log of total assets.

,*****, indicate significant difference between means for the parent bank and its subsidiaries at the $1 \%$, $5 \%$ and $10 \%$ levels, respectively, in a two-tailed test. 
The $R O A$ for the parent banks is almost four times higher than that of their foreign subsidiaries, and therefore they seem at first to be more profitable. Kosmidou et al. (2007) reported similar results, in which he also documented that the median ROA for Greek bank subsidiaries was lower than its parent bank. At the same time, however, parent banks have significantly lower NIM than their subsidiaries. As net interest income constitutes the largest part of the banks' income, the underperformance of subsidiaries in comparison to the parent bank can be seen as unusual. In particular, the level of noninterest income does not differ significantly between the parent bank and its subsidiaries. In addition, foreign subsidiaries have lower loan loss reserves than their parent banks. As a result, higher overhead costs seem to be the only explanation, which explains the lower profitability of the subsidiary relative to the parent banks. The results may thus indicate that either operating abroad is very costly or multinational banks use overhead expenses to transfer some of the income to the home markets, which may also explain the reported underperformance of foreign subsidiaries in comparison to domestic banks in some of the existing studies.

The foreign subsidiaries also differ significantly from their parent banks in terms of their assets and liability structures. The volume of total assets and capital ratios of the parent bank are significantly higher than it is in the subsidiaries, which can be attributed to the different models of operation in host markets. It may also explain why parent banks produced slightly fewer loans as a percentage of total assets than did their foreign subsidiaries. Surprisingly, however, foreign subsidiaries have significantly higher deposits as a percentage of assets than parent banks do. Indeed, Demirgüç-Kunt and Huzinga (1999) reported that those foreign banks that had higher levels of deposits also had higher levels of overhead costs, which they attributed to high branching expenses. Hence, the high level of deposits can be another explanation for the high overhead costs of the foreign subsidiaries in comparison to their parent banks. Moreover, the high level of deposits may also explain the reason for the higher level of securities held by subsidiaries relative to parent banks, which additionally may have a negative impact on profitability. Those results contradict, however, those of Peek et al. (1999), who documented that, in the US, foreign banks have problems attracting deposits and, as a result, were underperforming in comparison to domestic banks.

Overall, the results confirm that parent banks differ to a large extent from their foreign subsidiaries in terms of profitability, costs and balance sheet structures. As a result, the question of what determines the profitability of foreign subsidiaries relative to their parent banks seems to be justified.

\section{Methodology and Empirical Results}

I investigate the determinants of the performance of foreign subsidiaries relative to their parent banks using the following specification:

$$
\begin{aligned}
\text { Performance }_{i j, f, t}= & \alpha_{0}+\beta_{1} S_{i, f, t}+\beta_{2} P_{j, h, t}+\beta_{3} P P_{j, h, t} \\
& +\beta_{4} H_{f, t}+\beta_{5} H H_{f, t}+\varepsilon_{i, t}
\end{aligned}
$$

where $\Delta$ Performance is one of the three variables calculated as the difference in the performance of the subsidiary $i$ in host country $f$ and its parent bank $j$ in home country $h$ at time $t ; S_{i}$ and $P_{j}$ are bank-level variables showing the asset and liability structure of the subsidiary and its parent bank; $P P$ are variables calculated as the differences in efficiency variables for the parent bank and the average values for all banks in the home country; $H_{f}$ are country variables for the host country; $\mathrm{HH}$ is a matrix of dummy variables that captures the distance between the home and host country. Furthermore, $\alpha_{0}$ is a constant, and $\varepsilon_{i, t}$ is an error term.

The main specification is estimated using the fixed effects model, whereas the preference for it over a random effects model is based on the use of Breusch-Pagan and Hausman tests (Baltagi, 2001).The fixed-effects estimator is robust in the omission of any relevant time-invariant regressors (Johnston and DiNardo, 1997). On the other hand, a fixed-effects model removes any effect associated with time-invariant explanatory variables, while a random-effects model considers the association between these variables and the dependent variable. Hence, I accept the less restrictive random effects model in the study and take those variables into account. To control for serial correlation, I cluster the robust standard errors by the multinational bank.

A more generic generalized-method-of-moments (GMM) approach was also considered, yet its use with small sample sizes and a large number of instruments as in this study has generated results that appear valid but could be invalid (Roodman, 2009). In addition, whereas the GMM procedure may be more efficient than a fixed or random effects model when either heteroskedasticity or serial correlation are present, Woolridge (2001) argues that since basic econometric methods can use robust inference techniques, thus allowing for arbitrary heteroskedasticity or serial correlation, the gains from using GMM may be immaterial.

\subsection{Basic Empirical Results}

In the first four columns of Table 3 , the results are presented for estimations using the fixed effects regression, while the next four columns show the results of estimations using the random effects regression with timeinvariant variables.

Among the foreign bank internal factors, the results show that if foreign bank subsidiaries have low loan provisions and overhead costs than they are more profitable than the parent banks. The results are in line with the literature, which shows the foreign banks outperform domestic banks as they have lower loan loss provisions and costs. Moreover, the results show that smaller and well-capitalized subsidiaries are more profitable than their parent banks. However, the coefficient for size is negative and significant only in the fixed effects regression. While, in the random effects regression it changes it signs and is positive in two of the specification. Hence, the results for the size are inconsistence, while all other coefficients remain unchanged in all the regressions.

The ownership-specific variables $d R O A$ and $d N I M$ presenting the performance of the parent bank in the home markets are significant, yet they are negatively related to 
the subsidiaries' profitability. This means that foreign subsidiaries are outperforming the parent bank when the latter is underperforming relative to its peers in the home market. Consequently, it seems that the ownership factor is not an advantage in the first place and does not have an impact on subsidiaries' performance abroad. On the other hand, the results also suggest that going abroad may improve the profitability of multinational banks, which underperform in the home market. It could also explain why banks decide to expand abroad even as their subsidiaries underperform as compared to domestic banks. The results also reveal that the effects of parent bank assets or its structures on its foreign subsidiaries' profitability are weak. The lack of size effects on subsidiaries is consistent with the previous results of Williams (1998) and Kosmidou (2007).

Table 3. Foreign subsidiaries performance relative to its parent bank

\begin{tabular}{|c|c|c|c|c|c|c|c|c|}
\hline \multirow{2}{*}{$\begin{array}{c}\text { Dependent } \\
\text { variable }\end{array}$} & \multicolumn{4}{|c|}{ Fixed-effects regression } & \multicolumn{4}{|c|}{ Random-effects regression } \\
\hline & ROA & ROA & NIM & NIM & ROA & ROA & NIM & NIM \\
\hline \multirow[t]{2}{*}{ Loss } & $-0.01^{* * *}$ & $-0.01^{* * *}$ & $-0.00^{* *}$ & $-0.00^{*}$ & $-0.01^{* * *}$ & $-0.01^{* * *}$ & $-0.00^{* *}$ & -0.00 \\
\hline & $(0.00)$ & $(0.00)$ & $(0.00)$ & $(0.00)$ & $(0.00)$ & $(0.00)$ & $(0.00)$ & $(0.00)$ \\
\hline \multirow[t]{2}{*}{ Loans $_{s}$} & 0.01 & 0.01 & 0.01 & 0.01 & 0.01 & 0.00 & $0.01^{* * * *}$ & 0.01 \\
\hline & $(0.01)$ & $(0.01)$ & $(0.01)$ & $(0.01)$ & $(0.01)$ & $(0.01)$ & $(0.00)$ & $(0.01)$ \\
\hline \multirow[t]{2}{*}{ Costs $_{\mathrm{s}}$} & $-0.18^{* * *}$ & $-0.22^{* * *}$ & $0.29^{* * * *}$ & $0.28^{* * *}$ & $-0.11^{* * * *}$ & $-0.15^{* * *}$ & $0.31^{* * * *}$ & $0.24^{* * *}$ \\
\hline & $(0.04)$ & $(0.05)$ & $(0.07)$ & $(0.08)$ & $(0.04)$ & $(0.06)$ & $(0.08)$ & $(0.09)$ \\
\hline \multirow[t]{2}{*}{ Capital $_{\mathrm{s}}$} & $0.04^{* *}$ & $0.04^{* *}$ & $0.03^{* * *}$ & $0.02^{* * *}$ & $0.05^{* * *}$ & $0.05^{* * *}$ & $0.03^{* * * *}$ & $0.03^{* *}$ \\
\hline & $(0.02)$ & $(0.02)$ & $(0.01)$ & $(0.01)$ & $(0.01)$ & $(0.02)$ & $(0.01)$ & $(0.01)$ \\
\hline \multirow[t]{2}{*}{ Assets $_{\mathrm{s}}$} & $-0.24^{* *}$ & $-0.23^{* *}$ & $-0.15^{*}$ & $-0.13^{*}$ & $0.08^{*}$ & 0.00 & $0.16^{* *}$ & -0.01 \\
\hline & $(0.10)$ & $(0.10)$ & $(0.09)$ & $(0.07)$ & $(0.04)$ & $(0.05)$ & $(0.07)$ & $(0.05)$ \\
\hline \multirow{2}{*}{ Loans $_{\mathrm{p}}$} & -0.01 & -0.02 & 0.00 & 0.00 & 0.00 & -0.01 & 0.01 & $-0.01^{*}$ \\
\hline & $(0.02)$ & $(0.01)$ & $(0.01)$ & $(0.01)$ & $(0.01)$ & $(0.01)$ & $(0.01)$ & $(0.00)$ \\
\hline \multirow[t]{2}{*}{ Assets $_{\mathrm{s}}$} & 0.07 & 0.15 & 0.12 & 0.14 & $-0.10^{* * *}$ & -0.06 & $-0.08^{* *}$ & 0.01 \\
\hline & $(0.14)$ & $(0.14)$ & $(0.11)$ & $(0.10)$ & $(0.04)$ & $(0.04)$ & $(0.04)$ & $(0.04)$ \\
\hline \multirow[t]{2}{*}{$\mathrm{dROA}_{\mathrm{p}}$} & $-0.99^{* * *}$ & $-1.00^{* * *}$ & & & $-0.98^{* * *}$ & $-0.99^{* * *}$ & & \\
\hline & $(0.01)$ & $(0.01)$ & & & $(0.01)$ & $(0.03)$ & & \\
\hline \multirow[t]{2}{*}{$\mathrm{dNIM}_{\mathrm{p}}$} & & & $-0.99^{* * *}$ & $-1.00^{* * *}$ & & & $-0.98^{* * *}$ & $-1.01^{* * *}$ \\
\hline & & & $(0.01)$ & $(0.01)$ & & & $(0.01)$ & $(0.01)$ \\
\hline \multirow[t]{2}{*}{ GDP } & & -0.20 & & $-1.30^{* *}$ & & $-0.43^{* * *}$ & & $-1.35^{* * *}$ \\
\hline & & $(0.48)$ & & $(0.64)$ & & $(0.13)$ & & $(0.16)$ \\
\hline \multirow[t]{2}{*}{ Growth } & & -3.01 & & $-9.84^{* * *}$ & & -1.41 & & $-8.73^{* *}$ \\
\hline & & (3.39) & & (3.29) & & (2.98) & & (4.09) \\
\hline \multirow[t]{2}{*}{ CR5 } & & $3.30^{* * *}$ & & 1.55 & & $1.08^{*}$ & & 0.15 \\
\hline & & (1.05) & & (1.97) & & $(0.65)$ & & (1.10) \\
\hline \multirow[t]{2}{*}{ Region } & & & & & & 0.22 & & 0.69 \\
\hline & & & & & & $(0.33)$ & & $(0.42)$ \\
\hline \multirow[t]{2}{*}{ Law } & & & & & & $0.88^{* * * *}$ & & $1.03^{* * *}$ \\
\hline & & & & & & $(0.31)$ & & $(0.36)$ \\
\hline \multirow[t]{2}{*}{ Constant } & 2.30 & 1.99 & 1.74 & 10.79 & -0.19 & $3.32^{* *}$ & 0.55 & $14.00^{* * *}$ \\
\hline & (1.91) & $(4.82)$ & (1.60) & (7.04) & $(0.81)$ & (1.55) & $(0.93)$ & (1.67) \\
\hline Year dummies & Yes & Yes & Yes & Yes & Yes & Yes & Yes & Yes \\
\hline $\mathrm{N}$ & 2883 & 2706 & 2847 & 2670 & 2883 & 1905 & 2847 & 1882 \\
\hline $\mathrm{R}_{\text {overall }}^{2}$ & 0.59 & 0.59 & 0.53 & 0.62 & 0.65 & 0.66 & 0.61 & 0.70 \\
\hline $\mathrm{R}_{\text {within }}^{2}$ & 0.67 & 0.68 & 0.67 & 0.67 & 0.67 & 0.67 & 0.67 & 0.67 \\
\hline $\mathrm{R}_{\text {between }}^{2}$ & 0.61 & 0.61 & 0.57 & 0.70 & 0.72 & 0.72 & 0.68 & 0.80 \\
\hline
\end{tabular}

Note: Variables are defined in Table 1. Variables $\mathrm{x}_{\mathrm{S}}$ and $\mathrm{x}_{\mathrm{p}}$ are for foreign bank subsidiaries or its parent banks, respectively. Robust standard errors are reported in parentheses and they are clustered by multinational banks. ${ }^{* * *},{ }^{* *}$ and ${ }^{*}$ correspond to $1 \%$, 5\%, and $10 \%$ level of significance respectively.

The location-specific variables are important only to some extent. The results confirm that foreign banks are more profitable in low developed countries, which is in line with the existing literature. Moreover, the declining economic growth in the host countries positively affects the net interest margins of the subsidiary. Hence, the results confirm that subsidiaries are less prone to hosts' economic cycles. One explanation for the results is that subsidiaries have a different structure for loans than domestic banks do, which allows them to keep their profitability high during economic downturns (Clarke et al., 2001). Indeed, it may be assumed that subsidiaries, due to the support of the parent bank, may use the economic uncertainty in the host country to increase their market share as well as their interest margins. The results also show that foreign banks outperform its parent banks high concentrated banking sectors. Consequently, this finding may again confirm that foreign banks are performing better in less developed countries.

Finally, in line with the literature the results show that foreign banks outperform its parent banks when the host and home country share the same legal system. In contrast, regional proximity between the host and home markets does not have an effect on foreign bank performance.

\subsection{Subsidiaries in Developed and Developing Countries}

As the existing studies present mixed results due to the host country's economic development, the sample is partitioned into developed and developing economies. Splitting the sample enables me to address the question of 
whether the profitability of subsidiaries related to parent banks is different in economically diverse countries. The regression is estimated using fixed and random models and the results do not differ significantly from each other. Therefore, only the results for the random model are presented for the sake of brevity.

The results, in Table 4, confirm that different factors determine the performance of subsidiaries in developed and developing countries. In emerging markets, the coefficient for loan loss provision is negative in three of four specifications, while in the regression for the developed countries it is only significant in one of the specifications. Hence, the quality of loan portfolio is more important in emerging markets than in developed countries. Moreover, the coefficient for loans is positive and significant for developing countries, when the dependent variable is the difference in net interest margin between foreign bank subsidiaries and parent bank. Hence, the results document that, in emerging markets, subsidiaries' profitability is determined by loan activity, while to lesser extent it is important in developed countries. Moreover, when the net interest margin is used as dependent variable the coefficient for overhead costs is positive and significant. Demirgüç-Kunt and Huzinga (1999) attributed higher levels of overhead costs to branching expenses and higher levels of deposits. While, DeYoung and Nolle, 1996 showed funding is an important determinant in explaining foreign subsidiaries' performance, whereas loan activity may not be. Indeed, high overhead costs are negatively related to $R O A$, while loans are not significant. Consequently, higher level of deposits may lead to higher net interest margin, but it does not translate to higher overall performance of the subsidiary relative to its parent bank.

Table 4. Foreign subsidiaries performance in developed and developing countries

\begin{tabular}{|c|c|c|c|c|c|c|c|c|}
\hline \multirow{2}{*}{$\begin{array}{l}\text { Dependent } \\
\text { variable }\end{array}$} & \multicolumn{4}{|c|}{ Developed countries } & \multicolumn{4}{|c|}{ Developing countries } \\
\hline & ROA & ROA & NIM & NIM & ROA & ROA & NIM & NIM \\
\hline \multirow[t]{2}{*}{ Loss } & $-0.01^{* * *}$ & -0.00 & -0.00 & -0.00 & $-0.02^{* * *}$ & $-0.01^{* * *}$ & $-0.01^{* *}$ & -0.00 \\
\hline & $(0.00)$ & $(0.00)$ & $(0.00)$ & $(0.00)$ & $(0.00)$ & $(0.01)$ & $(0.00)$ & $(0.00)$ \\
\hline \multirow[t]{2}{*}{ Loans $_{s}$} & 0.00 & 0.00 & 0.01 & 0.01 & 0.01 & 0.01 & $0.02^{* * *}$ & $0.02^{* * *}$ \\
\hline & $(0.01)$ & $(0.01)$ & $(0.01)$ & $(0.01)$ & $(0.01)$ & $(0.01)$ & $(0.01)$ & $(0.01)$ \\
\hline \multirow[t]{2}{*}{ Costs $_{\mathrm{s}}$} & $-0.32^{* *}$ & $-0.44^{* *}$ & $0.19^{*}$ & 0.15 & -0.04 & -0.04 & $0.32^{* * *}$ & $0.26^{* *}$ \\
\hline & $(0.15)$ & $(0.19)$ & $(0.10)$ & $(0.11)$ & $(0.05)$ & $(0.07)$ & $(0.09)$ & $(0.10)$ \\
\hline \multirow[t]{2}{*}{ Capital $_{\mathrm{s}}$} & $0.08^{* * *}$ & $0.08^{* * *}$ & $0.02^{* * *}$ & $0.02^{* * * *}$ & 0.03 & 0.03 & $0.03^{* * *}$ & $0.03^{* *}$ \\
\hline & $(0.02)$ & $(0.03)$ & $(0.00)$ & $(0.01)$ & $(0.02)$ & $(0.02)$ & $(0.01)$ & $(0.01)$ \\
\hline \multirow[t]{2}{*}{ Assets $_{\mathrm{s}}$} & -0.13 & $-0.35^{* *}$ & -0.05 & -0.02 & $0.10^{* * * *}$ & $0.06^{*}$ & $0.15^{* *}$ & 0.04 \\
\hline & $(0.09)$ & $(0.17)$ & $(0.05)$ & $(0.04)$ & $(0.03)$ & $(0.03)$ & $(0.07)$ & $(0.06)$ \\
\hline \multirow[t]{2}{*}{ Loans $_{\mathrm{p}}$} & -0.00 & -0.01 & 0.01 & 0.00 & 0.01 & 0.00 & 0.00 & -0.01 \\
\hline & $(0.01)$ & $(0.01)$ & $(0.01)$ & $(0.01)$ & $(0.01)$ & $(0.01)$ & $(0.01)$ & $(0.01)$ \\
\hline \multirow[t]{2}{*}{ Assets $_{\mathrm{s}}$} & -0.06 & -0.01 & -0.01 & -0.03 & -0.06 & $-0.08^{*}$ & 0.02 & 0.01 \\
\hline & $(0.06)$ & $(0.08)$ & $(0.06)$ & $(0.07)$ & $(0.04)$ & $(0.04)$ & $(0.05)$ & $(0.05)$ \\
\hline \multirow[t]{2}{*}{$\mathrm{dROA}_{\mathrm{p}}$} & $-1.02^{* * *}$ & $-1.04^{* * *}$ & & & $-0.96^{* * *}$ & $-0.97^{* * *}$ & & \\
\hline & $(0.02)$ & $(0.02)$ & & & $(0.01)$ & $(0.03)$ & & \\
\hline \multirow[t]{2}{*}{$\mathrm{dNIM}_{\mathrm{p}}$} & & & $-1.00^{* * *}$ & $-1.01^{* * *}$ & & & $-0.97^{* * *}$ & $-1.02^{* * *}$ \\
\hline & & & $(0.01)$ & $(0.01)$ & & & $(0.01)$ & $(0.01)$ \\
\hline \multirow[t]{2}{*}{ GDP } & & $1.20^{*}$ & & $-0.50^{*}$ & & $-0.80^{* * *}$ & & $-1.80^{* * *}$ \\
\hline & & $(0.65)$ & & $(0.26)$ & & $(0.24)$ & & $(0.35)$ \\
\hline \multirow[t]{2}{*}{ Growth } & & -1.98 & & 1.28 & & -0.81 & & $-8.26^{* *}$ \\
\hline & & (6.89) & & (2.66) & & (3.10) & & (3.64) \\
\hline \multirow[t]{2}{*}{ CR5 } & & $3.18^{* * *}$ & & -0.03 & & 0.01 & & 0.42 \\
\hline & & $(1.20)$ & & $(0.35)$ & & $(1.11)$ & & $(2.08)$ \\
\hline \multirow[t]{2}{*}{ Region } & & $0.98^{*}$ & & 0.04 & & 0.23 & & 0.70 \\
\hline & & $(0.56)$ & & $(0.21)$ & & $(0.47)$ & & $(0.65)$ \\
\hline \multirow[t]{2}{*}{ Law } & & $1.41^{* *}$ & & $0.67^{* *}$ & & 0.76 & & 0.30 \\
\hline & & (0.69) & & $(0.30)$ & & $(0.55)$ & & $(0.90)$ \\
\hline \multirow[t]{2}{*}{ Constant } & 0.64 & $-12.91^{*}$ & 1.00 & $6.25^{* *}$ & -1.00 & 0.00 & -1.29 & $15.74^{* * *}$ \\
\hline & (1.13) & $(6.60)$ & $(0.96)$ & (2.99) & (1.69) & $(0.00)$ & $(1.46)$ & (3.78) \\
\hline Year dummies & Yes & Yes & Yes & Yes & Yes & Yes & Yes & Yes \\
\hline $\mathrm{N}$ & 1314 & 855 & 1299 & 850 & 1569 & 1050 & 1548 & 1032 \\
\hline $\mathrm{R}_{\text {overall }}^{2}$ & 0.71 & 0.71 & 0.75 & 0.84 & 0.65 & 0.67 & 0.60 & 0.63 \\
\hline $\mathrm{R}_{\text {within }}^{2}$ & 0.76 & 0.73 & 0.84 & 0.84 & 0.64 & 0.66 & 0.64 & 0.62 \\
\hline $\mathrm{R}_{\text {between }}^{2}$ & 0.71 & 0.71 & 0.86 & 0.94 & 0.76 & 0.79 & 0.64 & 0.73 \\
\hline
\end{tabular}

Note: Variables are defined in Table 1. Variables $\mathrm{X}_{\mathrm{S}}$ and $\mathrm{x}_{\mathrm{P}}$ are for foreign bank subsidiaries or its parent banks, respectively. Robust standard errors are reported in parentheses and they are clustered by multinational banks. ${ }^{* * *}$, ${ }^{* *}$ and ${ }^{*}$ correspond to $1 \%$, $5 \%$, and $10 \%$ level of significance respectively.

The results, for both groups of countries, confirm again for NIM the coefficient for Equity is positive but is that the high capitalization of the subsidiaries has a positive effect on their profitability relative to its parent bank. Moreover, in developed countries, the higher capitalization of the subsidiary is both positively related to ROA and NIM. While, developed countries the coefficient is significant when the dependent variable is $R O A$, while statistically insignificant. In developing countries large foreign banks by assets are outperforming its parent banks. In contrast, in developed countries the coefficient for assets is negative but significant in one of the four specifications. Those differences may indicate the different models of banks in those countries, whereas in 
developing countries foreign banks are often larger as the parent banks acquired them in privatization or bailout processes in the past. The results verify the previous finding showing that subsidiaries perform well when the parent bank is underperforming in the home market. As in the main regressions, the coefficients $d R O A$ and $d N I M$ are negative and highly significant in all specifications.

The results show that the location-specific factors are also different for foreign subsidiary performance in developing countries than developed countries. In developed countries foreign bank tend to outperform the parent banks in more developed economies than the home markets. However, they have higher net interest margins in less developed economies. In developing countries foreign banks tend to outperform the parent bank in terms of profitability and net interest margin when the level of economic development is low. Additionally, they report higher net interest margin when the economic growth is also low. An explanation for these results is that foreign subsidiaries profit from underdevelopment, whereas they are less affected by economic turmoil in the host countries owing to the different structures of clients as compared to domestic banks. Moreover, it can be assumed that, as a result of economic uncertainty in the host countries, foreign subsidiaries may improve their bargain situation and hence their profitability as they are able to charge more from their customers for their services. Interestingly, however, is the fact the high concentration of the banking sector is positive for developed countries but it is significant in only one of the specification.

The results reveal that the distance between the home and host country is only important for the profitability of foreign subsidiaries in developed countries. The coefficient Region is however only positive and statistically significant when the dependent variable is $R O A$. This could mean that the geographical proximity of the subsidiary to its parent bank determines its profitability but to lesser extend its net interest margins. However, the coefficient Law is positive and significant in all of the regressions for developed countries. This means that subsidiaries in developed countries are more profitable when they are in closer to the home market. In contrast both coefficients are not statistical significant in all the regressions in developing countries. Hence, the results contrast the findings of Claessens and van Horen (2009), who documented that the geographical proximity determines foreign bank profitability in developing countries.

\subsection{Robustness Checks}

Another approach for studying the performance of foreign bank subsidiaries is to estimate the probability of being the best and worst subsidiary relative to the parent bank. To do this, discrete variables for best and worst performance were constructed. A bank was qualified as best (worst) subsidiary performer when it was in the highest (lowest) quartile based on ROA or NIM. Then, a logit with random effects was employed, which allowed me to estimate the probability of subsidiaries' performance abroad. In the regression, the dependent variable is one if a foreign subsidiary is the best (worst) performer and zero otherwise, while its probability is explained by the same set of covariates as in the main regression.
Table 5 reports the parameter estimates for the probability of subsidiaries' performance abroad, which are in general in line with the previous findings. Among the internal banks' factors, the coefficients for Loss, Loans, Equity and Assets enter the mode for best and worst performing foreign bank subsidiaries as significant in most of the specifications but with opposite signs. The results also confirm the main findings and document the fact that subsidiaries are performing better (worse) abroad when the parent bank is underperforming (overperforming) in the home market. In the best performing subsidiary regression, the loan coefficient for parent banks is negative and significant.

In the regression for best performing subsidiaries the variable for loss loan provision is negative and significant in three of the four specifications. In opposition, for worst performing banks it is positive but only significant when the dependent variable is ROA. In contrast, the variable Loan is negative and highly significant when determinants for worst performing subsidiaries are estimated. While, for best performing subsidiaries it is positive but only significant when the dependent variable is NIM. It means the low level of loans negatively determinants the profitability of the subsidiaries relative to its parent banks. However, high level of loans does not translate automatically to outperformance as the quality of loans is an important determinant of its profitability.

The variable Costs is positive and significantly related to ROA for best and worst performing subsidiaries. However, the coefficient for the variable is negative and significant for the worst performing subsidiaries when the difference in the net interest margin is used as the dependent variable. As high overhead costs are positively related to higher level of deposits the underperformance of the subsidiaries may be related to funding costs. Indeed, the results of DeYoung and Nolle's (1996) implied that foreign banks had a distinct disadvantage primarily driven by excess expenditures on purchased funds as they lacked the ability to build their base of core deposits in the host country. Similar findings were presented by Peek et al. (1999), who reported that banks acquired by foreigners depend less on core deposits and more on purchased funds than domestic banks do. Consequently, one of the reasons for the underperforming of the foreign banks can be attributed to problems of attracting deposits as source of financing.

Problems of funding may also explain why the subsidiaries with high capitalization are outperforming parent banks. In contrast, the regressions for worst performing subsidiaries reveal that a low level of equity has a negative impact on its profitability. Similarly, size of the foreign banks is positively related to profitability of the best performing subsidiaries. In contrast, the coefficient for Assets is negative for the worst performing subsidiaries. However, the coefficient is only twice significant for the best performing subsidiaries and only once for the worst performing subsidiaries.

Again, in line with the main results, the regression reveals that foreign subsidiaries are performing better in less developed countries. The coefficient for GDP is negative and significant for best performing banks. In contrast, for worst performing banks it is positive but only significant when the dependent variable is difference in net interest margins. The results also show that high 
concentration in the banking sector is only important for profitability of the best performing banks. While, the coefficient for region is not significant for best performing banks the results show that foreign subsidiaries underperform relative to the parent bank when they are in different region than the parent bank. Finally, the results verify also that legal distance between the host and home market has a significant impact on the performance of the subsidiary abroad. The coefficient for law is positive and significant for best performing banks, whereas it is negative and significant for worst performing loans. The results are in line with the Classens and van Horen (2009) who reported that the relative performance of foreign banks is better when the geographical, cultural and institutional distance is small.

Table 5. Best and worst performing foreign subsidiaries relative to its parent bank

\begin{tabular}{|c|c|c|c|c|c|c|c|c|}
\hline \multirow{2}{*}{$\begin{array}{c}\text { Dependent } \\
\text { variable }\end{array}$} & \multicolumn{4}{|c|}{ Best performing subsidiaries } & \multicolumn{4}{|c|}{ Worst performing subsidiaries } \\
\hline & ROA & ROA & NIM & NIM & ROA & ROA & NIM & NIM \\
\hline \multirow[t]{2}{*}{ Loss } & $-0.01^{* * *}$ & $-0.00^{* * *}$ & $-0.01^{* * *}$ & -0.00 & $0.01^{* * *}$ & $0.01^{* * *}$ & 0.00 & -0.00 \\
\hline & $(0.00)$ & $(0.00)$ & $(0.00)$ & $(0.00)$ & $(0.00)$ & $(0.00)$ & $(0.00)$ & $(0.00)$ \\
\hline \multirow[t]{2}{*}{ Loans $_{s}$} & -0.00 & -0.00 & $0.01^{* *}$ & $0.01^{* *}$ & $-0.02^{* * *}$ & $-0.02^{* * *}$ & $-0.04^{* * *}$ & $-0.03^{* * *}$ \\
\hline & $(0.00)$ & $(0.01)$ & $(0.01)$ & $(0.01)$ & $(0.01)$ & $(0.01)$ & $(0.01)$ & $(0.01)$ \\
\hline \multirow[t]{2}{*}{ Costs $_{\mathrm{s}}$} & $0.06^{* *}$ & 0.03 & $0.29^{* * *}$ & $0.20^{* * *}$ & $0.15^{* * *}$ & $0.16^{* * *}$ & $-0.13^{* * *}$ & $-0.08^{* *}$ \\
\hline & $(0.02)$ & $(0.03)$ & $(0.03)$ & $(0.03)$ & $(0.02)$ & $(0.03)$ & $(0.03)$ & $(0.03)$ \\
\hline \multirow[t]{2}{*}{ Capital $_{\mathrm{s}}$} & $0.08^{* * *}$ & $0.07^{* * *}$ & $0.04^{* * *}$ & $0.03^{* * *}$ & $-0.01 *$ & -0.01 & $-0.03^{* * *}$ & $-0.03^{* *}$ \\
\hline & $(0.01)$ & $(0.01)$ & $(0.01)$ & $(0.01)$ & $(0.01)$ & $(0.01)$ & $(0.01)$ & $(0.01)$ \\
\hline \multirow[t]{2}{*}{ Assets $_{\mathrm{s}}$} & $0.07^{*}$ & -0.03 & $0.23^{* * *}$ & 0.04 & -0.05 & -0.07 & $-0.21^{* * *}$ & -0.11 \\
\hline & $(0.04)$ & $(0.05)$ & $(0.05)$ & $(0.05)$ & $(0.04)$ & $(0.06)$ & $(0.06)$ & $(0.07)$ \\
\hline \multirow[t]{2}{*}{ Loans $_{p}$} & 0.01 & -0.01 & 0.01 & -0.00 & $-0.01^{* *}$ & 0.00 & -0.01 & $0.02^{* *}$ \\
\hline & $(0.01)$ & $(0.01)$ & $(0.01)$ & $(0.01)$ & $(0.01)$ & $(0.01)$ & $(0.01)$ & $(0.01)$ \\
\hline \multirow[t]{2}{*}{ Assets $_{\mathrm{s}}$} & $-0.16^{* * *}$ & -0.10 & $-0.30^{* * *}$ & -0.10 & 0.02 & 0.04 & 0.05 & 0.01 \\
\hline & $(0.05)$ & $(0.06)$ & $(0.07)$ & $(0.07)$ & $(0.06)$ & $(0.07)$ & $(0.07)$ & (0.08) \\
\hline \multirow[t]{2}{*}{$\mathrm{dROA}_{\mathrm{p}}$} & $-1.13^{* * * *}$ & $-1.47^{* * * *}$ & & & $1.38^{* * * *}$ & $1.78^{* * * *}$ & & \\
\hline & $(0.11)$ & $(0.16)$ & & & $(0.10)$ & $(0.16)$ & & \\
\hline \multirow[t]{2}{*}{$\mathrm{dNIM}_{\mathrm{p}}$} & & & $-0.80^{* * *}$ & $-1.47^{* * *}$ & & & $1.93^{* * *}$ & $2.20^{* * *}$ \\
\hline & & & $(0.10)$ & $(0.17)$ & & & $(0.15)$ & $(0.20)$ \\
\hline \multirow[t]{2}{*}{ GDP } & & $-0.70^{* * *}$ & & $-2.23^{* * *}$ & & 0.07 & & $1.27^{* * *}$ \\
\hline & & (0.13) & & $(0.21)$ & & $(0.16)$ & & $(0.20)$ \\
\hline \multirow[t]{2}{*}{ Growth } & & -0.10 & & -1.88 & & 0.21 & & -3.45 \\
\hline & & (2.11) & & $(2.81)$ & & (2.48) & & (3.66) \\
\hline \multirow[t]{2}{*}{ CR5 } & & $1.75^{* *}$ & & -1.02 & & 1.16 & & 1.27 \\
\hline & & $(0.70)$ & & $(0.84)$ & & $(0.86)$ & & $(0.86)$ \\
\hline \multirow[t]{2}{*}{ Region } & & -0.34 & & 0.47 & & -0.77 & & $-2.12^{* * *}$ \\
\hline & & (0.39) & & $(0.45)$ & & $(0.47)$ & & $(0.52)$ \\
\hline \multirow[t]{2}{*}{ Law } & & $1.89^{* * *}$ & & 1.13 & & $-2.07^{* * *}$ & & $-1.80^{* *}$ \\
\hline & & $(0.60)$ & & $(0.77)$ & & $(0.76)$ & & $(0.71)$ \\
\hline \multirow[t]{2}{*}{ Constant } & -1.20 & $5.77^{* * *}$ & $-2.49^{* * *}$ & $19.03^{* * *}$ & $-3.93^{* * *}$ & $-5.76^{* * *}$ & $-3.22^{* * *}$ & $-15.84^{* * *}$ \\
\hline & $(0.76)$ & $(1.49)$ & $(0.92)$ & $(2.03)$ & $(0.88)$ & (1.91) & (1.07) & $(2.34)$ \\
\hline $\mathrm{N}$ & 2883 & 1905 & 2847 & 1882 & 2883 & 1905 & 2847 & 1882 \\
\hline Wald $\chi^{2}$ & $198^{* * *}$ & $163^{* * *}$ & $168^{* * *}$ & $162^{* * *}$ & $240^{* * * *}$ & $151^{* * *}$ & $209^{* * * *}$ & $151^{* * * *}$ \\
\hline
\end{tabular}

Note: Variables are defined in Table 1. Variables $\mathrm{x}_{\mathrm{S}}$ and $\mathrm{x}_{\mathrm{P}}$ are for foreign bank subsidiaries or its parent banks, respectively. Robust standard errors are reported in parentheses. ${ }^{* * *},{ }^{* *}$ and ${ }^{*}$ correspond to $1 \%, 5 \%$, and $10 \%$ level of significance respectively.

Lastly, I ensure that all of the findings are robust by conducting additional tests using alternative econometric methods, changing the specifications and exogenous variables, or altering the sample data. The main results of this study remain unaffected throughout all of these robustness checks, but are not shown for brevity.

\section{Conclusions}

When multinational banks expand abroad, they allocate capital to their subsidiaries in the host country. Consequently, it should be expected that those subsidiaries perform equally or even better than their parent banks do in the home market. However, in the literature, little is known on how foreign subsidiaries perform relative to their parent banks and what drives the outcome. Understanding this relationship seems to be especially relevant as the existing studies documented that foreign subsidiaries underperform in developed countries, while the opposite is in emerging markets. On the other hand the existing studies used as a peer group domestic banks, which differ in developed and developing countries significantly. Hence, employing parent banks to evaluate the foreign banks performance may not only provide an answer whether they outperform them abroad but also when.

Indeed, the results of univariate analyses show that foreign bank subsidiaries are on average less profitable than their parent banks are, which may put in question the 
rationality of rapid expansion, which has been observed in many markets in the last few decades. On the other hand, the results also show that the difference in profitability can be attributed to the bank-specific factors and host country determinants. Indeed, the results show that subsidiaries are more likely to outperform parent banks in developing markets. Consequently, this study confirm the existing finding showing that foreign banks perform better in emerging markets than in developed countries.

In line with the literature the study also shows that foreign subsidiaries perform better when they have low loss provision and are well capitalized. The results present also a negative causation between foreign banks overhead costs and its profitability. Overhead costs are however positively related to subsidiaries net interest margin. An explanation for the results could be the funding structure of the foreign banks as Demirgüç-Kunt and Huzinga (1999) found that higher overhead costs are related to higher levels of deposits. The access to deposits may explain higher net interest margin, but the results also show that it does not translated into the overall higher profitability of the subsidiary. As for size of the subsidiary the results are diverse. The results show a negative and significant relationship between subsidiaries assets in developed countries, but in contrast, in developing countries it was the opposite.

The study also documents that foreign subsidiaries perform better than their parent banks when the latter is inefficient in terms of profitability in the home market. These finding suggest that foreign subsidiaries are especially profitable for less competitive multinational banks, which may increase their overall results through foreign entry. This might also mean that the home efficiency may not always be transferable. The fact is strengthen by the results showing parent banks size is not important in explaining subsidiaries performance abroad. Moreover, in contrast to de Haas and Lelyveld (2010), the results do show any evidence of the substitution effects in lending between parent banks and subsidiaries.

Lastly, the results also present that the distance factors between home and host countries have different effects on the profitability of the subsidiaries relative to the parent bank. Among the distance factors, legal proximity is positive and significant for all the subsidiaries. The coefficient for legal proximity was however insignificant in the regressions for subsidiaries in developing countries. In contrast, it was positive and significant for subsidiaries in developed countries. Moreover, for subsidiaries in developed countries also the coefficient for region was positive and significant. Consequently, the proximity between host and home country seems to be more important in explaining the performance of subsidiaries in developed countries than in developed.

While this study has tried to address the issue of whether foreign subsidiaries perform better abroad relative to their parent banks, it does not address an equally interesting question: Why do multinational banks continue to enter new markets when their subsidiaries underperform abroad? There are a number of possible explanations. First, multinational banks may transfer income from the host country. Consequently, the existing results may be biased and foreign subsidiaries' profitability can be much higher than previously expected. Second, multinational banks may follow their customers abroad to better service their needs and to retain them (Grosse and Goldberg, 1991). In this case, it is the overall profitability of the relationship with that customer that is relevant, not merely the marginal contribution to profits made by the foreign subsidiary's bank. Third, multinational banking organizations may enter foreign markets to obtain benefits from international diversification (Buch at al., 2010).

All of these possible arguments are likely, but more studies are needed to understand the ongoing existing relationship between the multinational bank and its foreign subsidiary fully in terms of profitability, which is left for further research.

\section{References}

[1] Baltagi, B., 2001. Econometric Analysis of Panel Data, 2nd ed., John Wiley and Sons, Chichester.

[2] Beck, T., Demirgüç-Kunt, A., 2009. Financial institutions and markets across countries and over time: Data and analysis. World Bank Policy Research Working Paper No. 4943, World Bank.

[3] Berger, A. 1995. The relationship between capital and earnings in banking. Journal of Money, Credit and Banking 27, 432-456.

[4] Berger, A.N, Hanweck, G., Humphrey, D. 1987. Competitive viability in banking: Scale, scope and product mix economies. Journal of Monetary Economics 20, 501-520.

[5] Berger, A.N., DeYoung, R., Genay, H., Udell, G.F., 2000. The globalization of financial institutions: Evidence from cross-border banking performance. Brookings-Wharton Papers on Financial Services 3, 23-158.

[6] Berger, A.N., Klapper, L.F., Udell, G. F., 2001. The ability of banks to lend to informationally opaque small businesses. Journal of Banking and Finance 25(12), 2127-2167.

[7] Buch, C. M., DeLong, G., 2004. Cross-border bank mergers: What lures the rare animal? Journal of Banking and Finance 28(9), 2077-2102.

[8] Buch, C. M., Driscoll, J. C., Ostergaard, C., 2010. Cross-border diversification in bank asset portfolios. International Finance 13(1), 79-108.

[9] Bourke, P., 1989. Concentration and other determinants of bank profitability in Europe, North America and Australia. Journal of Banking and Finance 13, 65-79.

[10] Claessens, S., Demirgüc-Kunt, A., H. Huizinga, 1998. How does foreign entry affect the domestic banking market? World Bank Policy Research Working Paper 1918, World Bank.

[11] Claessens, S., van Horen N., 2009. Being a foreigner among domestic banks: Asset or liability? IMF Working Papers 09/273, International Monetary Fund.

[12] Clarke, G. R. G., Cull, R., Martinez Peria, M.S., 2001. Does foreign bank penetration reduce access to credit in developing countries? Evidence from asking borrowers. World Bank Policy Research Working Paper No. 2716, World Bank.

[13] Correa, R., 2008. Cross-border bank acquisitions: Is there a performance effect? International Finance Discussion Papers 922, Board of Governors of the Federal Reserve.

[14] Crystal, J., Dages, B.G., Goldberg, L.S., 2001. Does foreign ownership contribute to sounder banks in emerging markets? The Latin American experience. Staff Report No. 137, Federal Reserve Bank of New York.

[15] Demirgüç-Kunt, A., Huizinga H., 2000. Financial structure and bank profitability. World Bank Working Paper.

[16] Focarelli, D., Pozzolo, A.F., 2001. The patterns of cross-border bank mergers and shareholdings in OECD countries. Journal of Banking and Finance 25, 2305-2337.

[17] Demirgüç-Kunt, A., Huizinga, H., 1999. Determinants of commercial banks interest margins and profitability: Some international evidence, World Bank Economic Review 13, 379-408.

[18] DeYoung, R., Nolle, D.E., 1996. Foreign-owned banks in the US: Buying market share of earning it? Journal of Money, Credit, and Banking 28, 622-636.

[19] Grosse, R. Goldberg, L. G., 1991. Foreign bank activity in the United States: An analysis by country of origin. Journal of Banking and Finance 15, 1093-1112. 
[20] Haas de, R., van Lelyveld, I., 2010. Internal capital markets and lending by multinational bank subsidiaries. Journal of Financial Intermediation 19(1), 1-25.

[21] Johnston, J., DiNardo, J., 1997. Econometric Methods,4 ed., The McGraw-Hill Companies, New York.

[22] Kosmidou, K., Pasiouras, F., Tsaklanganos, A., 2007. Domestic and multinational determinants of foreign bank profits: The case of Greek banks operating abroad. Journal of Multinational Financial Management 17(1), 1-15.

[23] Laeven, L., Valencia, F., 2010. Resolution of banking crises: The good, the bad, and the ugly. IMF Working Paper 10/146.

[24] Leveen, S., Praveen, J., 1994. A desegregated approach to the analysis of the effects of bank foreign ownership on bank performance. Journal of Applied Business Research 10, 121-129.

[25] Minh To, H., Tripe, D., 2002. Factors influencing the performance of foreign owned banks in New Zealand. Journal of International Financial Markets, Institutions and Money 12, 341-357.

[26] Molyneux, P., Remolona, E., Seth, R., 1998. Modeling foreign bank performance and lending behavior. Financial Markets, Institutions and Instruments 7, 26-41.

[27] Moulyneux, P., Thornton, J., 1992. Determinants of European bank profitability: A Note. Journal of Banking and Finance 16, 1173-1178.

[28] Peek, J., Rosengren, E.S., Kasirye, F., 1999. The poor performance of foreign bank subsidiaries: Were the problems acquired or created? Journal of Banking and Finance 23(2-4), 579-604.

[29] Rivard, R.J., Thomas, C.R., 1997. The effect of interstate banking on large bank holding company profitability and risk. Journal of Economics and Business 49, 61-76.
[30] Roodman, D., 2009. A note on the theme of too many instruments. Oxford Bulletin of Economics and Statistics 71(1), 135-158.

[31] Smirlock, M., 1985. Evidence on the (non) relationship between concentration and profitability in banking. Journal of Money, Credit and Banking 17 (1), 69-83.

[32] Sturm, J.-E., Williams, B., 2010. What determines differences in foreign bank efficiency? Australian evidence. Journal of International Financial Markets, Institutions and Money 20(3), 284-309.

[33] Ursacki T., Vertinsky, I., 1992. Choice of entry timing and scale by foreign banks in Japan and Korea. Journal of Banking and Finance 16, 405-421.

[34] Wall, L., 1985. Why are some banks more profitable than others? Journal of Bank Research 15, 240-56.

[35] Williams, B., 1996. Determinants of the performance of Japanese financial institutions in Australia 1987-1992. Applied Economics 28, 1153-1165.

[36] Williams, B., 1998. A pooled study of the profits and size of foreign banks in Australia, Journal of Multinational Financial Management 8, 211-231.

[37] Williams B., 2003. Domestic and international determinants of bank profits: Foreign banks in Australia. Journal of Banking and Finance 27, 1185-1210.

[38] Woolridge, A., 2001. Applications of generalized method of moments estimation. Journal of Economic Perspectives 15, 87100 . 